\title{
Effects of Packing Media and the Insertion of Vegetation on the Performance of Biological Trickling Filters
}

\author{
Vinícius Ferreira Martins (D), Greicelene Jesus da Silva (D) and Alisson Carraro Borges *(D) \\ Department of Agricultural Engineering, Federal University of Viçosa, Viçosa 36570-900, Brazil; \\ vinicius.f.m@hotmail.com (V.F.M.); greicelene.dasilva@gmail.com (G.J.d.S.) \\ * Correspondence: borges@ufv.br
}

check for updates

Citation: Martins, V.F.; Silva, G.J.d.; Borges, A.C. Effects of Packing Media and the Insertion of Vegetation on the Performance of Biological Trickling Filters. Water 2021, 13, 1735. https:// doi.org/10.3390/w13131735

Academic Editor:

Ewa Wojciechowska

Received: 28 May 2021

Accepted: 20 June 2021

Published: 23 June 2021

Publisher's Note: MDPI stays neutral with regard to jurisdictional claims in published maps and institutional affiliations.

Copyright: (c) 2021 by the authors. Licensee MDPI, Basel, Switzerland. This article is an open access article distributed under the terms and conditions of the Creative Commons Attribution (CC BY) license (https:/ / creativecommons.org/licenses/by/ $4.0 /)$.

\begin{abstract}
The use of the plant Chrysopogon zizanioides (vetiver), able to develop under adverse conditions while removing a great number of pollutants, in constructed wetlands (CWs) is widely reported. Regarding the biological trickling filters (BTFs), the selection of the media is one of the most important factors in its performance. We investigated whether the addition of vegetation improves the efficiency of the basic parameters of BTFs with gravel. In addition, due to the properties of light expanded clay aggregate (LECA), we evaluated whether the support media composed of vetiver and LECA is able to increase the media's oxygenation. The efficiencies were $39,49,56$, and $49 \%$ for biochemical oxygen demand (BOD) and 27, 20, 12, and 31\%, for total Kjeldahl nitrogen (TKN) in $\mathrm{BTF}_{\mathrm{LV}}$ (vetiver with $\mathrm{LECA}$ ), $\mathrm{BTF}_{\mathrm{L}}$ (LECA only), $\mathrm{BTF}_{\mathrm{GV}}$ (vetiver with gravel) and $\mathrm{BTF}_{\mathrm{G}}$ (gravel only), respectively. LECA when associated with vetiver may have provided higher aeration of the filter, denoted by the higher nitrate effluent concentration $\left(0.35\right.$, against $0.03,0.06$, and $0.10 \mathrm{mg} \mathrm{L}^{-1}$ for $\mathrm{BTF}_{\mathrm{L}}, \mathrm{BTF}_{\mathrm{GV}}$, and $\mathrm{BTF}_{\mathrm{G}}$ ). Vetiver had no improvement on $\mathrm{BTF}$ s performance concerning $\mathrm{BOD}$. However, associated with LECA, its use could be viable to remove dissolved forms of nitrogen.
\end{abstract}

Keywords: vertical-flow constructed wetlands; vetiver grass; aerobic treatment; domestic wastewater; packing media

\section{Introduction}

Selecting appropriated sewage treatment methods is a difficult task in most developing countries due to financial constraints, lack of technically trained staff, and electricity shortages. Therefore, in these regions, there is a need to explore simplified technologies apart from conventional systems [1].

The biological wastewater treatment process is a widely used method to remove organic pollutants. Among these technologies, BTFs stand out. A BTF is a biofilter composed of a packing media as support for biofilm attachment, where microorganisms can biodegrade contaminants. BTFs are characterized by less space and time for removal of organic matter, a moderate demand of technical training required for operators, and resistance in case of power failures and shock loads, in comparison to other secondary wastewater treatment systems [1], beyond less sludge generation [2]. According to Von Sperling [3], BTF operation and maintenance costs can reach 30\% less than activated sludge systems. However, other studies estimate differences of $46-53 \%$ between both treatment systems [1,4].

The selection of the packing media is one of the most important factors in the performance of a trickling filter. Stone, gravel, or plastic beds are the most common support media used in BTFs [5]. According to Victoria [6], the stone beds are a coarse support media. Therefore, the dispersion of liquid occurs at small depths, causing complete moistening of the available surface and the support's configuration tends to delay the flow of liquid through the filter. Thus, lower hydraulic loads must be applied to avoid flooding and system failures. Almeida et al. [7] point out that in places where emission standards are 
more flexible, the use of stone beds may still be a possibility due to their cost. However, the removal of nitrogenous compounds and the final effluent's quality improvement due to restrictions in the emission standards led to the discovery of new functional aspects in BTFs.

Due to LECA characteristics, this material has been used in sorption experiments aiming to remove persistent pollutants [8] and nutrients from water [9], also as support media in alternatives water and wastewater treatment systems [10-12]. LECA is a lightweight material with a high capacity of nitrogen removal in CWs due to its high porosity and large surface area where oxygen is able to penetrate [13] and biomass to develop.

The use of plant species in CWs is extensive due to its influences on the efficiency of wetland systems: alteration in the hydraulic conductivity of the units, possibility of oxygen transfers through the root zone, the liberation of exudates, contaminant removal by the biofilm zone around the roots and nutrient uptakes. Chrysopogon zizanioides (common name vetiver grass) has been widely used in soil and water phytoremediation [14-16]. Vetiver is able to develop under adverse conditions while removing a great amount of contaminants [14,17] and nutrients in wastewater [18], presenting a high production of biomass. Zhao et al. [19] compared six species of plants in CWs, reporting that vetiver had the greater leaf biomass $\left(1.57 \mathrm{~kg} \mathrm{~m}^{-2}\right)$ due to its herbal properties and lower moisture contents. The radicular system, large and dense (3 to $4 \mathrm{~m}$ in the first year), is able to improve aeration in root zone [20], to support nutrient exchange and allow the growth of microbial community [21].

To the best of our knowledge, the effects of vegetation in the operation of BTFs have not yet been evaluated. Therefore, aiming at more sustainable projects and to expand the functional aspects of the BTF system, this study proposed to verify the possible benefits of vetiver in BTF systems. The association between gravel and vetiver is proposed to investigate whether the addition of vegetation improves the efficiency of the basic parameters of BTFs with gravel since it is a support media widely used for its low cost. Since the plant is highly resistant to adverse conditions, its development would not be compromised by the pollutants loading from the sewage studied. It was expected an assimilative capacity of nutrients, due to the high biomass production. In addition, the dense root system of vetiver (which can improve the oxygenation conditions of the media) could allow improvements in the removal of nutrients and organic matter in BTFs with a gravel bed. In addition, considering the high porosity and specific surface of LECA, we also evaluated whether the support media composed of vetiver and LECA was able to produce an increase in the oxygenation and nitrification rates of the media.

\section{Materials and Methods}

\subsection{Experimental Unit}

Sewage was passed through a screening and elevated by a pumping station before entering the primary clarifier, which was made of high-density polyethylene with $10 \mathrm{~m}^{3}$ of capacity. After the primary treatment, a distribution reservoir of $0.219 \mathrm{~m}^{3}$ was implemented in order to share equally the influent to the subsequent four BTFs in parallel. Followed by them, there were four secondary clarifiers (not being targeted by this survey), for the posttreatment of wastewater. The flow chart of the experimental unit is presented in Figure 1A. Figure $1 \mathrm{~B}$ shows an image of the experimental setup with the vegetation. Figure 1C shows a root of vetiver extracted from the BTF with gravel after the plant stabilization.

The four BTFs were built with the same dimensions, with $0.5 \mathrm{~m}^{3}$ capacity, structured in welded metal drums, with $0.60 \mathrm{~m}$ in diameter and $1.80 \mathrm{~m}$ high. The BTFs were filled with packing media to a height of $1.70 \mathrm{~m}$, leaving a freeboard of $0.10 \mathrm{~m}$ and a bottom for drainage of $0.20 \mathrm{~m}$. Cross-shaped fixed distributors were installed on the top of BTFs. These devices have been made with polyvinyl chloride (PVC) upper portion open tubes of $50 \mathrm{~mm}$ in diameter to avoid clogging. 


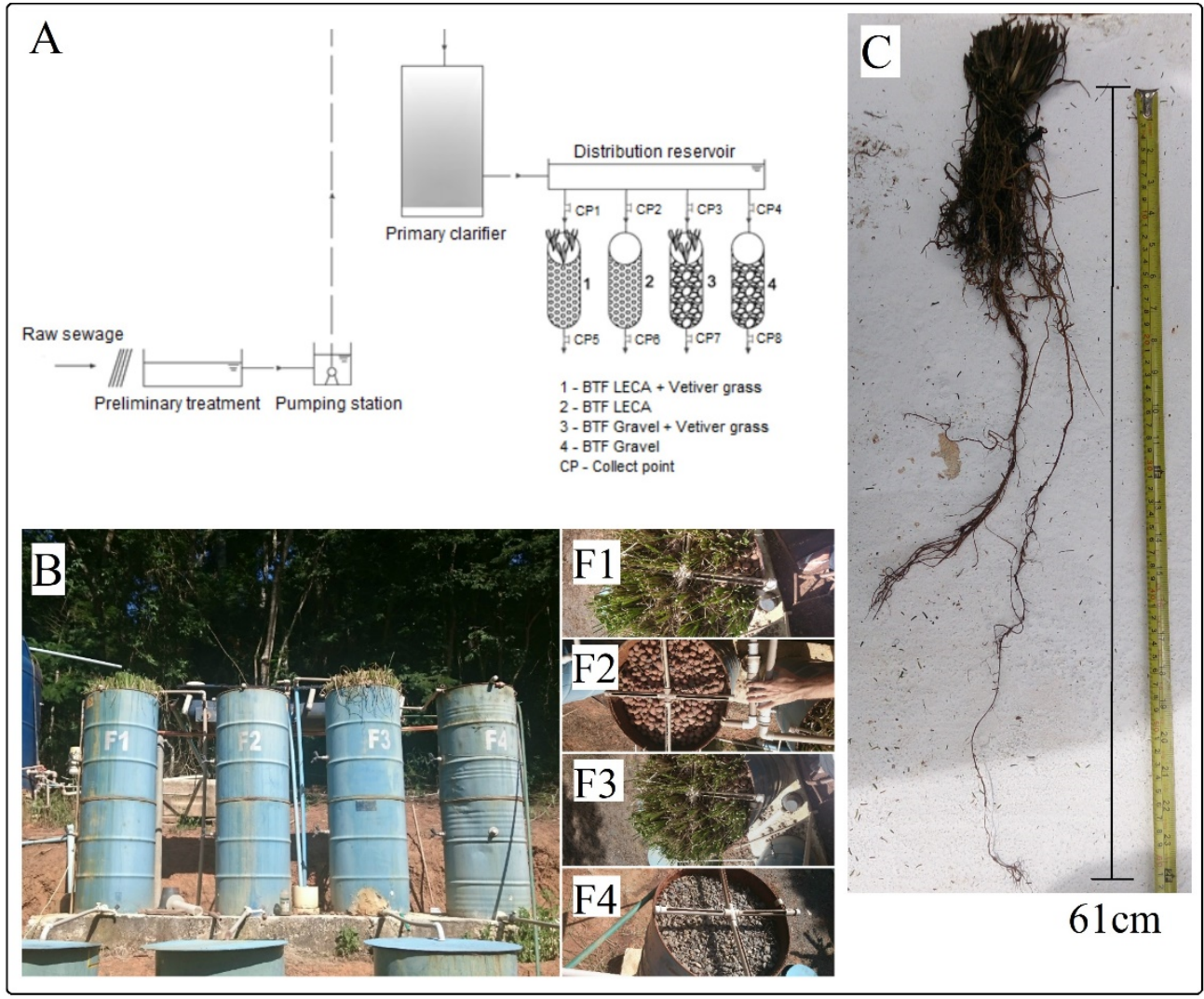

Figure 1. Flowchart of the experimental unit (A) and a digital image (taken after a shallow cut in the vegetation) of the BTF of gravel and LECA with and without vetiver (B). F1: BTF with LECA+ vetiver; F2: BTF with LECA; F3: BTF with gravel + vetiver; F4: BTF with gravel. (C) Vetiver root extracted from F3.

Two of the four BTFs belonging to the experiment were filled with LECA and two with Gravel "\#1". In two of the BTFs-one unit containing LECA and another containing gravel-were inserted the vetiver grasses.

Gravel \#1 has a specific weight of $1450 \mathrm{~kg} \mathrm{~m}^{-3}$ in comparison to $450 \mathrm{~kg} \mathrm{~m}^{-3}$ of LECA. The specific surface and void ratio of LECA is $270 \mathrm{~m}^{2} \mathrm{~m}^{-3}$ and $65 \%$, against $60 \mathrm{~m}^{2} \mathrm{~m}^{-3}$ and $50 \%$, respectively, for Gravel \#1 [22]. Gravel was used as support media because of its low cost and widespread use. LECA was also studied as an alternative filter media due to its lower specific weight, besides of higher specific surface and void ratio, in comparison to gravel.

The vegetated BTFs ( 1 and 3 ) behave like vertical-flow constructed wetlands. However, the designation "BTF" was maintained since the other units were not vegetated. A vertical unit configuration of the system was chosen due to the vertical growth of the vetiver. Thus, the settings and names of BTFs composing the system were as follows:

$$
\begin{gathered}
\mathrm{BTF}_{\mathrm{LV}}=\text { LECA media grown with vetiver grass } \\
\mathrm{BTF}_{\mathrm{L}}=\text { LECA media without vegetation } \\
\mathrm{BTF}_{\mathrm{GV}}=\text { gravel media grown with vetiver grass } \\
\mathrm{BTF}_{\mathrm{G}}=\text { gravel media without vegetation }
\end{gathered}
$$

Regarding vegetated filters, the vetiver grass was already established in the filters and its insertion occurred before the present study. As a control measure, before starting the 
operation of this experiment, the vetiver grass was pruned to $10 \mathrm{~cm}$ high from the media top surface (Figure 1B).

\subsection{Operational Conditions}

The hydraulic loading rate (HLR) adopted as an initial design parameter was $2.7 \mathrm{~m}^{3} \mathrm{~m}^{-2} \mathrm{~d}^{-1}$ and the organic loading rate (OLR) of BOD was $0.3 \mathrm{~kg} \mathrm{~m}^{-3} \mathrm{~d}^{-1}$, characterizing the BTFs as a low rate units [23]. The choice of this criterion was due to the simplicity involved in the operation and the satisfactory BOD removal efficiency, besides the no need to recycle the effluent. Furthermore, this loading rate is indicated for small capacity sewage treatment plants [23] and there is the possibility of nitrification occurrence. To design the low rate BTFs we adopted average BOD after post-primary clarifier equal to $200 \mathrm{mg} \mathrm{L}^{-1}$. Table 1 shows the operational parameters of each BTF.

Table 1. Operational characteristics in BTFs regarding flow, volume, OLR and HLR.

\begin{tabular}{ccc}
\hline Operating Characteristics & Value & Unit \\
\hline Influent flow rate (for each BTF) & 0.75 & $\mathrm{~m}^{3} \mathrm{~d}^{-1}$ \\
Adopted OLR as BOD & 0.3 & $\mathrm{~kg} \mathrm{~m}^{-3} \mathrm{~d}^{-1}$ \\
HLR & 2.7 & $\mathrm{~m}^{3} \mathrm{~m}^{-2} \mathrm{~d}^{-1}$ \\
Volume for each filter & 0.5 & $\mathrm{~m}^{3}$ \\
Adopted influent BOD & 200 & $\mathrm{mg} \mathrm{L}^{-1}$ \\
\hline
\end{tabular}

For the influent, a sampling with four collect points was performed in the output distribution tank called CP1, CP2, CP3, CP4 (Figure 1A), making up a composite sample. For the effluent, samples were collected at the output of each filter that composes the system, referred to as CP5, CP6, CP7, CP8.

Within 30 days of the startup system, the BTFs reached the steady-state and the biofilm establishment. Thereafter, the system was kept in continuous flow operation for 60 days.

\subsection{Analytical Procedures}

After the system reached a steady-state, the monitoring of the BTF was conducted. The sampling frequency was twice a week and the following physicochemical variables were analyzed: BOD, TKN, total ammonia nitrogen (TAN), nitrate $\left(\mathrm{N}^{-N_{3}}{ }^{-}\right)$, total phosphorus, dissolved oxygen (DO), and settleable solids. The nitrogen analysis measured as $\mathrm{N}^{-\mathrm{NO}_{3}}{ }^{-}$ was performed following the methodology of Yang et al. [24]. The analyses for the other variables were performed according to the Standard Methods for the Examination Water and Wastewater [25]. Table 2 shows the methods and apparatus used. Analyses of filtered BOD samples were also performed, using GF-1.47 mm glass fiber microfilters.

Table 2. Physical-chemical variables, methodology and devices used.

\begin{tabular}{cc}
\hline Physicochemical Variables & Method/Apparatus \\
\hline BOD & Hach HQ440D Digital Measurer \\
TKN & Semimicro Kjeldahl \\
TAN & Semimicro Kjeldahl \\
$\mathrm{N}^{-N_{3}-}$ & Colorimetry \\
Total Phosphorus & Spectrophotometry \\
Temperature & Hach MP-6 Sensor \\
pH & Hach MP-6 Sensor \\
OD & Hach HQ440D Digital Measurer \\
Settleable solids & Imhoff Cone \\
\hline
\end{tabular}

\subsection{Statistical Analysis}

A factorial statistical analysis of the data was performed in order to verify the contribution of the support media and vegetation on the differences found in the concentrations of crude BOD, nutrients, and DO in the filters. Montgomery [26] states that this is the 
appropriate method to evaluate experiments with more than one factor. The factorial statistical analysis allows evaluating the effects caused by each factor and also the consequence of the interaction between them.

The experiment was conducted according to a factorial $2 \times 2$, comprising four treatments, which consisted of the combination of the media (LECA or gravel) with vegetation (vetiver grass cultivation and without the vegetation) in a randomized block design. Each block was referred to a sample campaign so that there was the greater uniformity as possible inside each block.

A Shapiro-Wilk "W" test at a 5\% significance level was performed to verify the normality and the Bartlett test was used to investigate the homogeneity of variances (homoscedasticity) between the treatments. In a case of violation of any assumptions, the transformation of the original data in statistical analysis was performed, or a nonparametric Kruskal-Wallis at a 5\% significance level was used. When normality was observed, parametric statistics variance analysis (ANOVA) followed by Tukey test (5\%) were performed. ASSISTAT $^{\circledR} 7.7$ beta software was used for statistical analysis.

\section{Results and Discussion}

Figure 2 shows the box plot of total BOD and filtered BOD (Figure 2A), DO (Figure 2B), and settleable solids (Figure 2C). Data from BTFs influent and effluent concentrations regarding total phosphorus (Figure 2D), TAN/ TKN (Figure 2E), and $\mathrm{N}^{-\mathrm{NO}_{3}}{ }^{-}$(Figure 2F) are presented as well. The values shown refer only to the performance of the BTFs. Thus, the influent name is referred to the values of the post-primary clarifier and the effluent mentioned refers to the effluent passing through the BTFs.

A

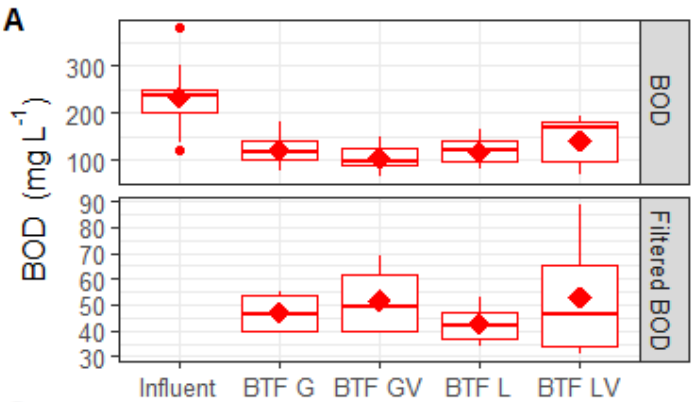

C
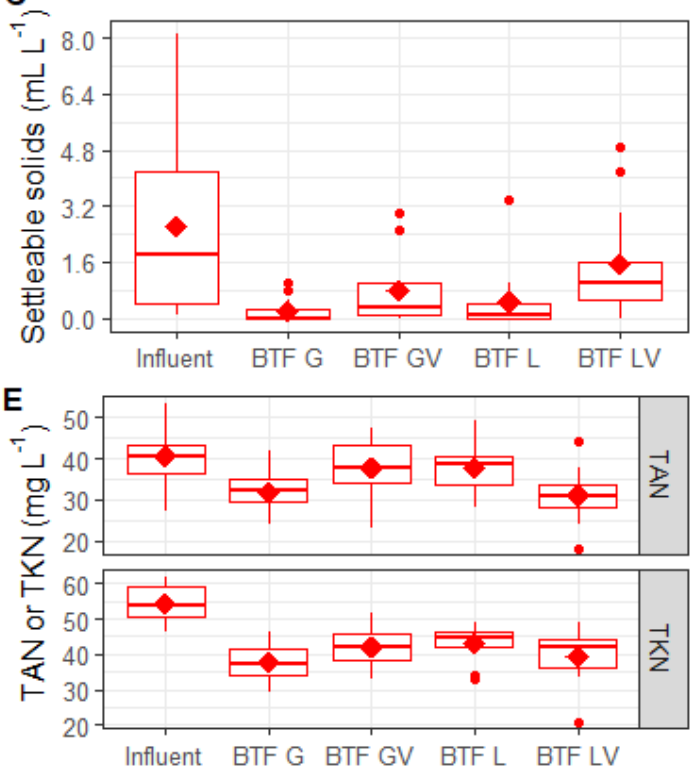

B

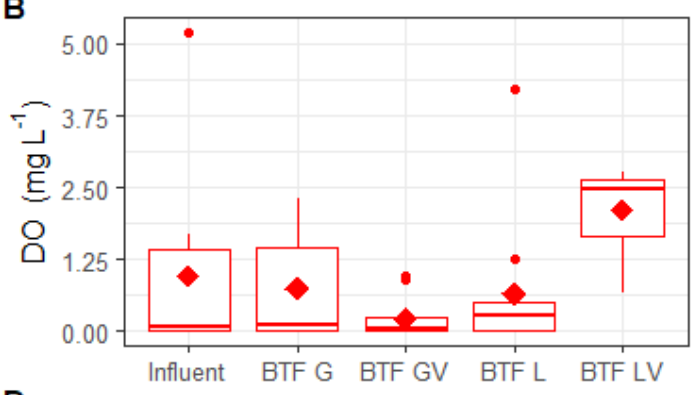

D

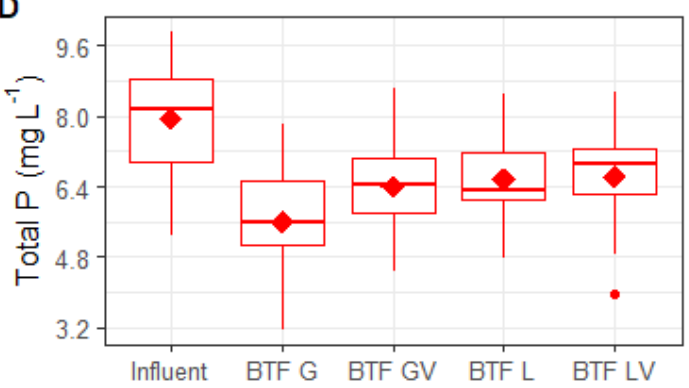

$\mathbf{F}$

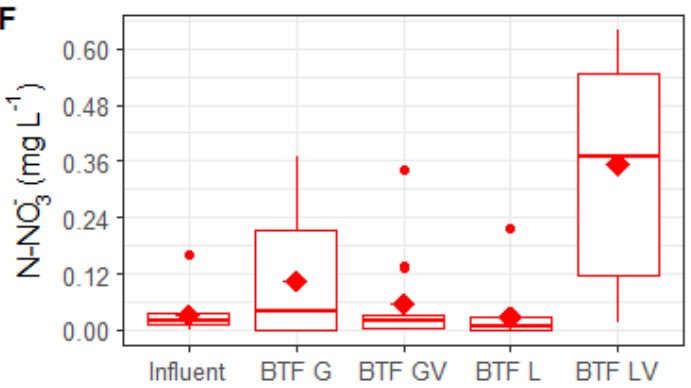

Figure 2. Box plot of filtered and not filtered BOD (A), DO (B), settleable solids (C), total phosphorus (D) and TKN/TAN (E) and ${\mathrm{N}-\mathrm{NO}_{3}}^{-}$(F) in each BTF unit. 


\subsection{Performance of Organic Matter and Settleable Solids Removal}

The average BOD influents and effluents were $234 \pm 79,142 \pm 52,119 \pm 31,104 \pm 26$, $120 \pm 32 \mathrm{mg} \mathrm{L}^{-1}$, for $\mathrm{BTF}_{\mathrm{LV}}, \mathrm{BTF}_{\mathrm{L}}, \mathrm{BTF}_{\mathrm{GV}}$, and $\mathrm{BTF}_{\mathrm{G}}$ respectively. The average efficiencies for BOD were $39,49,56$, and $49 \%$ for $\mathrm{BTF}_{\mathrm{LV}}, \mathrm{BTF}_{\mathrm{L}}, \mathrm{BTF}_{\mathrm{GV}}$ and $\mathrm{BTF}_{\mathrm{G}}$, respectively (Figure 2A). The values in general are lower than indicated in literature considering low rate BTFs. According to Ali et al. [1], BTFs achieve usually 85-90\% BOD and 80-85\% COD removal efficiencies after the second clarifier. The reasons that led to the obtained average values for BOD may be related to the high solid input contribution in the BTFs (Figure 2C) in which the system had not retained enough and due to the detachment of biofilm.

However, for filtered BOD, the average efficiencies were $77,82,78$, and $80 \%$ for $\mathrm{BTF}_{\mathrm{LV}}$, $\mathrm{BTF}_{\mathrm{L}}, \mathrm{BTF}_{\mathrm{GV}}$, and $\mathrm{BTF}_{\mathrm{G}}$, respectively. These satisfactory values regarding filtered $\mathrm{BOD}$ indicate a high capacity of removing dissolved BOD as most of the remaining BOD was in the particulate form. Part of this material can be removed in the secondary clarifiers, providing a lower level of suspended solids in the final effluent and consequently a lower concentration of organic matter in the receiving water body.

Table 3 shows results from the factorial statistical analysis, showing the effects caused by each factor (media and vegetation) and the effect caused by the interaction between them.

Table 3. Concentrations of BOD effluents in $\mathrm{mg} \mathrm{L}^{-1}$. Factorial analysis regarding the interaction between the media and vegetation in BTFs, besides of effects caused by each factor.

\begin{tabular}{ccc}
\hline \multirow{2}{*}{ BTF Media } & \multicolumn{2}{c}{ Vegetation } \\
\cline { 2 - 3 } & With Vetiver Grass & Without Vetiver Grass \\
\hline Gravel & $104 \mathrm{mg} \mathrm{L}^{-1} \mathrm{~b} \mathrm{~A}$ & $120 \mathrm{mg} \mathrm{L}^{-1}$ a A \\
LECA & $142 \mathrm{mg} \mathrm{L}^{-1}$ a A & $119 \mathrm{mg} \mathrm{L}^{-1}$ a B \\
\hline
\end{tabular}

$\mathrm{a}, \mathrm{b}$-Considering each media, means followed by the same lowercase letters (vertical direction) do not differ significantly by Tukey test at 5\% significance level; A, B-considering presence or absence of vegetation, means followed by the same uppercase letters (horizontal direction) do not differ significantly by way of the Tukey test at a $5 \%$ significance level.

We can observe in Table 3 that the units with gravel as support media differed significantly. The solids retention in the gravel might create a favorable environment for BOD removal, probably because this media worked as a barrier preventing a portion of the suspended solids to be routed out of the BTFs. Kishimoto et al. [27] evaluated the performance of trickling filters using two types of plastic media of the same material and concluded that the rougher surface retained twice more biomass of microorganisms than the smoother, contributing to greater COD removal. Furthermore, according to the same authors, the roughness of the filter media may prolong the hydraulic retention time. Therefore, despite its smaller void ratio and specific surface area compared to LECA, the rougher surface of the gravel media maybe has enabled better adherence and retention of the bacteria, besides prolonging retention time in comparison to LECA.

The higher settleable solids values in $\mathrm{BTF}_{\mathrm{LV}}$ effluent in comparison to the other BTFs (Figure 2C) can be explained by the use of media with different specific surface and structure which, according to Pérez et al. [28], could produce changes in the transfer and diffusion of nutrients to the packing media, causing different degrees of development and detachment of biofilms in BTFs. The uneven sloughing of slime layer is able to led high settleable solids in the effluent [1]. This discontinuity might be increased by the penetration of the roots while it grows. Furthermore, it is known that clay has a high void ratio, which is positive for providing a greater airflow into the system, but enables higher solids carryover out of the filter. These prerogatives might explain the higher levels of settleable solids in $\mathrm{BTF}_{\mathrm{LV}}$ of $1.5 \mathrm{mg} \mathrm{L}^{-1}$ against $0.5,0.8$ e $0.2 \mathrm{mg} \mathrm{L}^{-1}$ for $\mathrm{BTF}_{\mathrm{L}}, \mathrm{BTF}_{\mathrm{GV}}$, and $\mathrm{BTF}_{\mathrm{G}}$. For this parameter, $\mathrm{BTF}_{\mathrm{G}}$ has the lowest level, reaffirming the solids' retentions by this material. According to the results showed in Figure 2A, a significant part of BOD not removed from $\mathrm{BTF}_{\mathrm{LV}}$ may be settleable in a second clarifier. 
A large part of this BOD in the $\mathrm{BTF}_{\mathrm{LV}}$ effluent (Figure 2A) comes from the organic matter contained in the biofilm. It is indicated by the difference between the results of filtered and unfiltered effluent BOD, besides the higher value of settleable solids (Figure 2C). The Pérez et al. [28] statement, together with the vetiver performance described in the previous paragraph, can also explain the high variation of the unfiltered BOD caused by the uneven detachment of biofilm layers from different stages of degradation.

The $\mathrm{BTF}_{\mathrm{LV}}$ was the filter that showed the best results in terms of DO (Figure 2B), with a statistically significant average of $2.11 \mathrm{mg} \mathrm{L}^{-1}$ of $\mathrm{O}_{2}$ against $0.66,0.23$, and $0.75 \mathrm{mg} \mathrm{L}^{-1}$ to $\mathrm{BTF}_{\mathrm{L}}, \mathrm{BTF}_{\mathrm{GV}}$, and $\mathrm{BTF}_{\mathrm{G}}$, respectively. It is known that $\mathrm{DO}$ is an important parameter for the oxidation of nitrogen, influencing the performance of BTFs.

In Table 3, the presence of vetiver grass when analyzed individually had no improvement on the performance of BTFs, concerning BOD removal. According to Ali et al. [1], better aeration of the system contributes to the greater removal of organic matter in BTFs. However, the results found in the present study indicated the opposite: between $\mathrm{BTF}_{\mathrm{LV}}$ and $\mathrm{BTF}_{\mathrm{L}}$, the second option showed to be more efficient in removing organic matter. Queluz [29] found a lower BOD content in the final effluent for non-vegetated CW than for CW vegetated by Typha latifolia. According to the author, it is possible that this result occurred due to the release of exudates by the roots. Such a prerogative can explain what happened in the present study. There was no significant difference between both filters with gravel due to the solids retention previously mentioned.

Mendonça et al. [30] also did not find a significant influence of plant species for the removal of BOD. The authors state that BOD removal is more significantly related to other mechanisms such as physical (removal of particulate BOD) and microbiological (removal of soluble BOD) mechanisms. However, they emphasized the importance of vegetation for other processes.

\subsection{Performance for Phosphorus Removal}

Analyzing the phosphorus average in Figure 2D, a minimum difference between influent and effluent was observed. Unsatisfactory removal values were consistent with Kishimoto et al. [27] that used a BTF system with OLR ranging from 0.2 to $0.9 \mathrm{~kg} \mathrm{~m}^{-3} \mathrm{~d}^{-1}$ of BOD and HLR from 1 to $5 \mathrm{~m}^{3} \mathrm{~m}^{-2} \mathrm{~d}^{-1}$ (ranges that include the operational parameter employed in the present study) with influent concentration $3.0 \mathrm{mg} \mathrm{L}^{-1}$ of phosphorus and did not obtain removal of this parameter. The average concentrations of phosphorus effluent on the media and vegetation are shown in Table 4 . Statistical analysis shows no significant interaction between factors; therefore, its unfolding was not necessary.

Table 4. Total phosphorus concentrations on BTFs effluents.

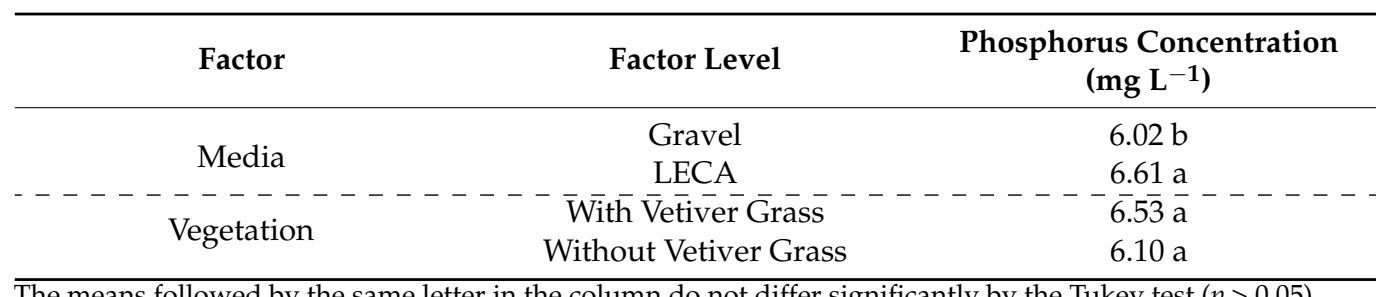

As can be seen in Table 4, the gravel media $\left(\mathrm{BTF}_{\mathrm{GV}}\right.$ and $\left.\mathrm{BTF}_{\mathrm{G}}\right)$ differed statistically from LECA $\left(B F_{L V}\right.$ and $\left.B T F_{L}\right)$, wherein the gravel provided better results for total phosphorus removal. $\mathrm{BTF}_{\mathrm{G}}$ had an average removal efficiency of $28 \%$ against $19 \%, 18 \%$, and $19 \%$ of $\mathrm{BTF}_{\mathrm{LV}}, \mathrm{BTF}_{\mathrm{L}}$, and $\mathrm{BTF}_{\mathrm{GV}}$, respectively. Regarding the support media performance, these results agree with those obtained by Lima et al. [31] in CWs. Comparing the performance of CWs without gravel vegetation and LECA as support media, the authors found close efficiency of $12 \%, 26 \%, 12 \%$, and $25 \%$ for CW with gravel only, gravel with vegetation, LECA only, and LECA with vegetation, respectively, at a retention time of $24 \mathrm{~h}$. However, at a retention time of $48 \mathrm{~h}$ and $72 \mathrm{~h}$, Lima et al. [31] concluded that the absorption through 
plants in CWs was probably the most significant mechanism of phosphorus removal in gravel and LECA.

It is known that BTFs usually have a lower retention time than CWs, causing less contact time between the wastewater and the vegetation. It was mentioned that a rougher media as gravel allows a longer retention time than LECA. Therefore, just as described for $\mathrm{BOD}$, in the present study the difference in the efficiency of $\mathrm{BTF}_{\mathrm{G}}$ (Table 4) may have occurred because it stayed longer retained on the media gravel than in LECA, increasing its retention time.

Considering the vegetation factor $\left(\mathrm{BTF}_{\mathrm{GV}}\right.$ and $\mathrm{BTF}_{\mathrm{LV}}$ : with the presence of vetiver grass and $\mathrm{BTF}_{\mathrm{G}}$ and $\mathrm{BTF}_{\mathrm{L}}$ : without the presence of vetiver) no statistical difference was noticed. This indicates that vegetation did not affect significantly phosphorus removal in BTF. It was noticed a reduced retention time of BTFs compared to CWs due to the high capacity of biomass assimilation and growth rate of vetiver. Despite that, a positive interference of vegetation in phosphorus removal in BTFs as in CWs did not occur, even on a small scale, as expected.

\subsection{Performance for Nitrogen Series Removal}

As can be seen in Figure $2 \mathrm{E}, \mathrm{F}$, the TKN removal efficiency for $\mathrm{BTF}_{\mathrm{LV}}, \mathrm{BTF}_{\mathrm{L}}, \mathrm{BTF} \mathrm{GV}_{\mathrm{V}}$ and $\mathrm{BTF}_{\mathrm{G}}$ was $27 \% ; 20 \% ; 12 \%$ and $31 \%$, respectively. For TAN, these values were $24 \% ; 7 \%$; $7 \%$ and $22 \%$, respectively.

The results of statistical analysis applied to TKN and TAN are shown in Table 5. No significant difference to the packing media or vegetation was observed. However, the interaction of these factors had a significant difference. Nonparametric statistics were used for nitrate due to no fulfillment of the assumptions for the parametric test.

Table 5. Concentrations (mg L ${ }^{-1}$ ) of TKN, TAN and N-NO ${ }_{3}^{-}$in BTFs effluents. For TKN and TAN, a factorial analysis was conducted regarding the interaction between the media and vegetation in BTFs, besides of effects caused by each factor. For $\mathrm{N}^{-\mathrm{NO}_{3}}{ }^{-}$, Kruskal-Wallis test was performed.

\begin{tabular}{|c|c|c|c|}
\hline \multirow[b]{2}{*}{ Nitrogen Specie } & \multirow[b]{2}{*}{ BTF Media } & \multicolumn{2}{|c|}{ Vegetation } \\
\hline & & Vetiver Grass & $\begin{array}{c}\text { Without Vetiver } \\
\text { Grass }\end{array}$ \\
\hline \multirow{6}{*}{$\begin{array}{c}\mathrm{TKN}\left(\mathrm{mg} \mathrm{L}^{-1}\right) \\
--------- \\
\mathrm{TAN}\left(\mathrm{mg} \mathrm{L}^{-1}\right) \\
--------- \\
\mathrm{N}^{-\mathrm{NO}_{3}}{ }^{-}\left(\mathrm{mg} \mathrm{L}^{-1}\right)\end{array}$} & Gravel & 42.1 a A & $37.6 \mathrm{~b} \mathrm{~B}$ \\
\hline & LECA & 39.5 a A & $43.1 \mathrm{a} \mathrm{A}$ \\
\hline & $\overline{\text { Gravei }} \overline{\mathrm{l}}$ & $\overline{3} 9 . \overline{\mathrm{a}} \overline{\mathrm{A}}$ & $\overline{32.7 \bar{b}}-\bar{B}^{--}$ \\
\hline & LECA & $31.0 \mathrm{~b} \mathrm{~B}$ & 37.7 a A \\
\hline & Ḡavēē & $-\overline{0.06} \mathrm{a}^{-}$ & $0.10 \bar{a}$ \\
\hline & LECA & $0.35 \mathrm{~b}$ & $0.03 \mathrm{a}$ \\
\hline
\end{tabular}

$\mathrm{a}, \mathrm{b}$-Considering each media, means followed by the same lowercase letters (vertical direction) do not differ significantly by Tukey test at $5 \%$ significance level; A, B-considering presence of absence of vegetation, means followed by the same uppercase letters (horizontal direction) do not differ significantly. Considering $\mathrm{N}_{-} \mathrm{NO}_{3}{ }^{-}$, different lowercase letters differ by Kruskal-Wallis at 5\% significance level.

Comparing the concentrations of $\mathrm{TKN}$, the $\mathrm{BTF}_{\mathrm{G}}$ was statistically different from the others, providing the best results for its removal (Table 5). The solids retention factor afforded by gravel helped in this result since the TKN composition is present in the nitrogen organic forms, which is more susceptible to removal physical processes, such as the retention of solids through the media.

Metcalf and Eddy [22] affirm that DO concentrations of $0.5 \mathrm{mg} \mathrm{L}^{-1}$ of $\mathrm{O}_{2}$ (Figure 2B) approximately, may cause denitrification due to the repression of nitrate-reducing enzymes. Considering TAN, both $\mathrm{BTF}_{\mathrm{LV}}$ and $\mathrm{BTF}_{\mathrm{G}}$ differed significantly (Table 5). Based on this result and according to the $\mathrm{DO}$ concentrations in Figure 2B, we can suggest that there was significant nitrification for $\mathrm{BTF}_{\mathrm{LV}}$ and $\mathrm{BTF}_{\mathrm{G}}$ in comparison with the other BTFs. Therefore, lower aeration of $\mathrm{BTF}_{\mathrm{L}}$ and $\mathrm{BTF}_{\mathrm{GV}}$ may have affected the $\mathrm{DO}$ levels which were insufficient to promote suitable conditions for nitrification. 
In Lima et al. [31] study, the influent used by the authors had a concentration of BOD and TKN close to the values found in the present study. The authors found average efficiencies for TKN removal of $12 \%, 21 \%, 9 \%$, and $19 \%$ to CW with only gravel, gravel with vegetation, only LECA and LECA with vegetation, respectively. They affirmed that there was no difference in the performance of CWs with or without vegetation for this parameter. Onodera et al. [32] operating a BTF with TKN influent of $30 \mathrm{mg} \mathrm{L}^{-1}$ obtained an effluent with $21 \mathrm{mg} \mathrm{L}^{-1}$ of TKN, and further by opening a window in BTF, the concentration reduced to $4 \mathrm{mg} \mathrm{L}^{-1}$ provided by the larger input of DO.

Moreover, competition between nitrifying and heterotrophic bacteria may also interfere in the nitrification process. Conditions of high concentrations of organic matter can provide a favorable environment predominance of heterotrophic bacteria, as these bacteria compete for oxygen and space, restricting the nitrifying microorganisms [33].

Regarding the $\mathrm{N}_{-} \mathrm{NO}_{3}{ }^{-}, \mathrm{BTF}_{\mathrm{LV}}$ was the most promising among the $\mathrm{BTF}$, which differed significantly from the others by the Kruskal-Wallis test at a 5\% significance level (Table 5). Distinct behavior of vetiver grass over the inserted media was observed. In the filter where vetiver grass was associated with $\mathrm{LECA}\left(\mathrm{BTF}_{\mathrm{LV}}\right)$, it was noticed a positive effect of vegetation in the BTF in two of the three forms of nitrogen measured. As exposed previously, $\mathrm{BTF}_{\mathrm{LV}}$ had also the highest concentration of DO (Figure 2B).

Ye and $\mathrm{Li}$ [34] emphasize that complete nitrification is only able to occur for DO above $1.5 \mathrm{mg} \mathrm{L}^{-1}$, which was achieved only by $\mathrm{BTF}_{\mathrm{LV}}$ to the detriment of the other BTFs. This prerogative can explain the results for $\mathrm{BTF}_{\mathrm{G}}$, which despite presenting TAN removal statistically significant from $\mathrm{BTF}_{\mathrm{L}}$ and $\mathrm{BTF}_{\mathrm{GV}}$, the $\mathrm{N}-\mathrm{NO}_{3}{ }^{-}$levels were not statistically equivalent to $\mathrm{BTF}_{\mathrm{LV}}$.

Angassa et al. [20] also obtained a significant increase in DO in CW planted with vetiver, even with decreasing hydraulic retention time. According to the authors, this result may have occurred due to oxygen release into the root zone area in the massive root hairs, resulting in more aeration. In the present study, the largest voids of LECA when associated with vetiver grassroots may have provided higher aeration of the filter and consequently a more favorable environment for the nitrification denoted by the higher $\mathrm{N}-\mathrm{NO}_{3}-$ concentration $\left(0.35 \mathrm{mg} \mathrm{L}^{-1}\right)$.

Vetiver is an easily adaptable plant in harsh environments. The cost-to-benefit of its implementation is high since the plant is able to assimilate a lot of biomass with a low initial cost [35]. Furthermore, the plant can survive for decades with little maintenance [36]. Regarding LECA, despite its high initial cost compared to gravel, the cost of acquisition can be compensated with the lifetime of this material, which is equivalent to the system lifetime. In this way, vetiver can be implemented in BTFs, together with LECA, when aiming for higher levels of nitrification at an affordable cost.

Given the vetiver seedling cost and considering a plant density equal to 15 units per $\mathrm{m}^{2}$ of the area in biofilter plant, according to the adopted by Darajeh et al. [37] for wetlands, an additional cost of implantation of US $\$ 6.00$ per $\mathrm{m}^{2}$ of planted area for implementation of $\mathrm{BTF}_{\mathrm{LV}}$ in relation to $\mathrm{BTF}_{\mathrm{L}}$ is estimated. In general, each filter has a different behavior, being more suitable according to a chosen variable. For $\mathrm{BTF}_{\mathrm{LV}}$, the dissolved oxygen variable stood out with the highest concentration among BTFs. Moreover, it reached the best result for TAN and $\mathrm{N}_{-} \mathrm{NO}_{3}{ }^{-}$as well. The $\mathrm{BTF}_{\mathrm{L}}$ and $\mathrm{BTF} \mathrm{FV}_{\mathrm{GV}}$ excelled with the lowest values for BOD. In addition, the $\mathrm{BTF}_{\mathrm{G}}$ had the lowest settleable solids and TKN values, besides good performance for TAN removal as well. Both $\mathrm{BTF}_{\mathrm{LV}}$ and $\mathrm{BTF}_{\mathrm{G}}$ had more variables that excelled, indicating the good settings from the studied filters.

\section{Conclusions}

From the results of this paper, it can be inferred that:

- Comparing the filters considering $\mathrm{BOD}$, best performance on $\mathrm{BTF}_{\mathrm{L}}$ and $\mathrm{BTF}_{\mathrm{GV}}$ were noticed.

- In the four filters, there was a poor removal of total phosphorus, with no significant difference between them. 
- Regarding TKN, the best performance was provided by $\mathrm{BTF}_{\mathrm{G}}$. Concerning TAN, the $\mathrm{BTF}_{\mathrm{LV}}$ and $\mathrm{BTF}_{\mathrm{G}}$ filters were better and, for $\mathrm{N}^{-\mathrm{NO}_{3}}{ }^{-}, \mathrm{BTF}_{\mathrm{LV}}$ had a superior performance than the other BTFs.

- Both $\mathrm{BTF}_{\mathrm{LV}}$ and $\mathrm{BTF}_{\mathrm{G}}$ had more variables that excelled (three for each), indicating the best settings from the studied filters.

Concerning the effects of vegetation on the performance of the studied BTFs, the presence of vetiver grass did not improve the performance of BTFs regarding BOD and phosphate removal in BTFs with LECA and gravel as support media. However, LECA associated with vetiver $\left(\mathrm{BTF}_{\mathrm{LV}}\right)$ presented the highest $\mathrm{DO}$, which reflected in its significantly best performance of TAN removal and nitrification capacity compared to packing media already consolidated (gravel).

This study investigated the advantages of the combined technologies LECA and vetiver to improve BTF operation. The results show that the use of aggregated vegetation in the BTF system along with LECA could be a viable technology to improve nitrification and removal of dissolved forms of nitrogen, besides being a low-cost and low-maintenance system. However, further investigation regarding the kinetics and optimization of a BTF with these settings must be performed.

Author Contributions: Conceptualization, A.C.B. and V.F.M.; data curation, V.F.M.; investigation, V.F.M. and G.J.d.S.; methodology, A.C.B. and V.F.M.; resources, A.C.B.; supervision, A.C.B.; validation, A.C.B.; visualization, V.F.M. and G.J.d.S.; and writing-original draft, V.F.M.; writing-review and editing, A.C.B. and G.J.d.S. All authors have read and agreed to the published version of the manuscript.

Funding: This research was financially supported by National Council for Scientific and Technological Development (CNPq Grant Process Number 144783/2019-3) and Coordination for the Improvement of Higher Education Personnel (CAPES Finance Code 001).

Data Availability Statement: The data presented in this study are available in the article itself and references cited.

Acknowledgments: We acknowledge CNPq and CAPES for funding. We also acknowledge Manoela M.S. Dias for her assistance on language editing.

Conflicts of Interest: The authors declare no conflict of interest.

\section{References}

1. Ali, I.; Khan, Z.M.; Peng, C.; Naz, I.; Sultan, M.; Ali, M.; Mahmood, M.H.; Niaz, Y. Identification and elucidation of the designing and operational issues of trickling filter systems for wastewater treatment. Pol. J. Environ. Stud. 2017, 26, 2431-2444. [CrossRef]

2. Dabrowski, W.; Karolinczak, B. Application of trickling filter and vertical flow constructed wetland bed to treat sewage from craft brewery. J. Ecol. Eng. 2019, 20, 211-217. [CrossRef]

3. Von Sperling, M. Introdução à Qualidade das Águas e ao Tratamento de Esgotos, 4th ed.; UFMG: Belo Horizonte, Brazil, 2014.

4. Zahin, M.W. Cost analysis of trickling-filtration and activated-sludge Plants for the treatment of municipal wastewater. In Proceedings of the Seventh Saudi Engineering Conference, Riyadh, Saudi Arabia, 2-5 December 2014; pp. 67-81.

5. Hasan, H.A.; Muhammad, M.H.; Ismail, N.I. A review of biological drinking water treatment technologies for contaminants removal from polluted water resources. J. Water Process Eng. 2020, 33, 101035. [CrossRef]

6. Victoria, J.A.R. Filtro Biológico Aeróbio-Anoxico para Remoção de Nitrogenio de Efluentes de Reatores UASB. Ph.D. Thesis, Universidade de São Paulo, São Paulo, Brazil, 2006.

7. Almeida, P.G.S.D.; Oliveira, S.C.; Chernicharo, C.A.D.L. Operation of trickling filters post-UASB reactors without the secondary sedimentation stage. Eng. Sanit. Ambient. 2011, 16, 271-280. [CrossRef]

8. Kalhori, E.M.; Al-Musawi, T.J.; Ghahramani, E.; Kazemian, H.; Zarrabi, M. Enhancement of the adsorption capacity of the light-weight expanded clay aggregate surface for the metronidazole antibiotic by coating with $\mathrm{MgO}$ nanoparticles: Studies on the kinetic, isotherm, and effects of environmental parameters. Chemosphere 2017, 175, 8-20. [CrossRef] [PubMed]

9. Łożyńska, J.; Bańkowska-Sobczak, A.; Popek, Z.; Dunalska, J.A. Selection of P-reactive materials for treatment of hypolimnetic water withdrawn from eutrophic lakes. Ecohydrol. Hydrobiol. 2020, 16, 276-288. [CrossRef]

10. Zapater-Pereyra, M.; Lavrnić, S.; van Dien, F.; van Bruggen, J.J.A.; Lens, P.N.L. Constructed wetroofs: A novel approach for the treatment and reuse of domestic wastewater. Ecol. Eng. 2016, 94, 545-554. [CrossRef] 
11. Łopata, M.; Czerniejewski, P.; Wiśniewski, G.; Czerniawski, R.; Drozdowski, J. The use of expanded clay aggregate for the pretreatment of surface waters on the example of a tributary of Lake Klasztorne Górne in Strzelce Krajeńskie. Limnol. Rev. 2017, 17, 3-9. [CrossRef]

12. Nguyen, X.C.; Nguyen, D.D.; Tran, Q.B.; Nguyen, T.T.H.; Tran, T.K.A.; Tran, T.C.P.; Nguyen, T.H.G.; Tran, T.N.T.; La, D.D.; Chang, S.W.; et al. Two-step system consisting of novel vertical flow and free water surface constructed wetland for effective sewage treatment and reuse. Bioresour. Technol. 2020, 306, 123095. [CrossRef]

13. Mlih, R.; Bydalek, F.; Klumpp, E.; Yaghi, N.; Bol, R.; Wenk, J. Light-expanded clay aggregate (LECA) as a substrate in constructed wetlands-A review. Ecol. Eng. 2020, 148, 105783. [CrossRef]

14. Banerjee, R.; Goswami, P.; Lavania, S.; Mukherjee, A.; Lavania, U.C. Vetiver grass is a potential candidate for phytoremediation of iron ore mine spoil dumps. Ecol. Eng. 2019, 132, 120-136. [CrossRef]

15. Taleei, M.M.; Ghomi, N.K.; Jozi, S.A. Arsenic Removal of Contaminated Soils by Phytoremediation of Vetiver Grass, Chara Algae and Water Hyacinth. Bull. Environ. Contam. Toxicol. 2019, 102, 134-139. [CrossRef]

16. Siyar, R.; Ardejani, F.D.; Farahbakhsh, M.; Norouzi, P.; Yavarzadeh, M.; Maghsoudy, S. Potential of Vetiver grass for the phytoremediation of a real multi-contaminated soil, assisted by electrokinetic. Chemosphere 2020, 246, 125802. [CrossRef] [PubMed]

17. Panja, S.; Sarkar, D.; Datta, R. Vetiver grass (Chrysopogon zizanioides) is capable of removing insensitive high explosives from munition industry wastewater. Chemosphere 2020, 209, 920-927. [CrossRef] [PubMed]

18. Gholipour, M.; Mehrabanjoubani, P.; Abdolzadeh, A.; Raghimi, M.; Seyedkhademi, S.; Karimi, E.; Sadeghipour, H.R. Facilitated decrease of anions and cations in influent and effluent of sewage treatment plant by vetiver grass (Chrysopogon zizanioides): The uptake of nitrate, nitrite, ammonium, and phosphate. Environ. Sci. Pollut. Res. 2020, 27, 21506-21516. [CrossRef]

19. Zhao, F.; Liu, C.; Rafiq, M.T.; Ding, Z.; Zeng, Z.; Aziz, R.; Yang, X. Screening wetland plants for nutrient uptake and bioenergy feedstock production. Int. J. Agric. Biol. 2014, 16, 213-216.

20. Angassa, K.; Leta, S.; Mulat, W.; Kloos, H.; Meers, E. Organic Matter and Nutrient Removal Performance of Horizontal Subsurface Flow Constructed Wetlands Planted with Phragmite karka and Vetiveria zizanioide for Treating Municipal Wastewater. Environ. Process. 2018, 5, 115-130. [CrossRef]

21. Raman, J.K.; Alves, C.M.; Gnansounou, E. A review on moringa tree and vetiver grass-Potential biorefinery feedstocks. Bioresour. Technol. 2018, 249, 1044-1051. [CrossRef]

22. Metcalf, W.; Eddy, P. Wastewater Engineering: Treatment and Reuse; McGraw-Hill Inc.: New York, NY, USA, 2015.

23. Jordão, E.P.; Pessoa, C.A. Tratamento de Esgotos Domésticos (Domestic Sewage Treatment); ABES: Rio de Janeiro, Brazil, 2014.

24. Yang, J.E.; Skogley, E.O.; Schaff, B.E.; Kim, J.J. A simple spectrophotometric determination of endosulfan in river water and soil. Soil Sci. Soc. Am. 1998, 62, 1108-1115. [CrossRef]

25. APHA/AWWA/WEF. Standard Method for Examination of Water and Wastewater; APHA/AWWA/WEF: Washington, DC, USA, 2017.

26. Montgomery, D.C. Design and Analysis of Experiments, 10th ed.; John Wiley \& Sons: New York, NY, USA, 2019; ISBN 9781119492443

27. Kishimoto, N.; Ohara, T.; Hinobayashi, J.; Hashimoto, T. Roughness and temperature effects on the filter media of a trickling filter for nitrification. Environ. Technol. 2014, 35, 1549-1555. [CrossRef]

28. Pérez, M.C.; Álvarez-Hornos, F.J.; San-Valero, P.; Marzal, P.; Gabaldón, C. Microbial community analysis in biotrickling filters treating isopropanol air emissions. Environ. Technol. 2013, 34, 2789-2798. [CrossRef] [PubMed]

29. Queluz, J.G.T. Eficiência de Alagados Construídos para o Tratamento de Águas Residuárias com Baixas Cargas Orgânicas. Ph.D. Thesis, Universidade Estadual Paulista, Botucatu, Brazil, 2016.

30. Mendonça, H.V.D.; Ribeiro, C.B.D.M.; Borges, A.C.; Bastos, R.R. Sistemas Alagados Construídos em Batelada: Remoção de Demanda Bioquímica de Oxigênio e regulação de $\mathrm{pH}$ no tratamento de efluentes de laticínios. Rev. Ambient. Agua 2015, 10, 442-453. [CrossRef]

31. Lima, M.X.; Carvalho, K.Q.; Passig, F.H.; Borges, A.C.; Filippe, T.C.; Azevedo, J.C.R.; Nagalli, A. Performance of different substrates in constructed wetlands planted with E. crassipes treating low-strength sewage under subtropical conditions. Sci. Total Environ. 2018, 630, 1365-1373. [CrossRef]

32. Onodera, T.; Tandukar, M.; Sugiyana, D.; Uemura, S.; Ohashi, A.; Harada, H. Development of a sixth-generation down-flow hanging sponge (DHS) reactor using rigid sponge media for post-treatment of UASB treating municipal sewage. Bioresour. Technol. 2014, 152, 93-100. [CrossRef] [PubMed]

33. Sepehri, A.; Sarrafzadeh, M. Activity enhancement of ammonia-oxidizing bacteria and nitrite-oxidizing bacteria in activated sludge process: Metabolite reduction and CO2 mitigation intensification process. Appl. Water Sci. 2019, 9, 1-12. [CrossRef]

34. Ye, F.X.; Li, Y. Enhancement of nitrogen removal in towery hybrid constructed wetland to treat domestic wastewater for small rural communities. Ecol. Eng. 2009, 35, 1043-1050. [CrossRef]

35. Danh, L.T.; Truong, P.; Mammucari, R.; Tran, T.; Foster, N. Vetiver grass, Vetiveria zizanioides: A choice plant for phytoremediation of heavy metals and organic wastes. Int. J. Phytoremediation 2009, 11, 664-691. [CrossRef]

36. Gnansounou, E.; Alves, C.M.; Raman, J.K. Multiple applications of vetiver grass-A review. Int. J. Environ. Sci. 2017, 2, $125-141$.

37. Darajeh, N.; Idris, A.; Masoumi, H.R.F.; Nourani, A.; Truong, P.; Sairi, N.A. Modeling BOD and COD removal from Palm Oil Mill Secondary Effluent in floating wetland by Chrysopogon zizanioides (L.) using response surface methodology. J. Environ. Manag. 2016, 181, 343-352. [CrossRef] 